\title{
The Effect of Sintering Time on Wear Resistance of Silicon Nitride
}

\author{
Zuzana Gábrišová'* , Alena Brusilová', Pavol Švec ${ }^{1}$ \\ 1 Institute of Technologies and Materials, Faculty of Mechanical Engineering, STU Bratislava, Námestie \\ Slobody 17, 81231 Bratislava, Slovak Republic \\ * Corresponding author's e-mail: zuzana.gabrisova@stuba.sk
}

\begin{abstract}
The effect of sintering time on the chosen mechanical and tribological properties of silicon nitride $\left(\mathrm{Si}_{3} \mathrm{~N}_{4}\right)$ with $5 \mathrm{wt}$ \% of yttrium aluminium garnet $\left(\mathrm{Y}_{3} \mathrm{Al}_{5} \mathrm{O}_{12}\right)$ ceramics was investigated. The $\mathrm{Si}_{3} \mathrm{~N}_{4}$ ceramics sintered for shorter time contained a larger portion of untransformed $\alpha-\mathrm{Si}_{3} \mathrm{~N}_{4}$ phase which has higher hardness compared to the tougher $\beta-\mathrm{Si}_{3} \mathrm{~N}_{4}$ phase. The fracture toughness of $\mathrm{Si}_{3} \mathrm{~N}_{4}$ ceramics increased with the prolongation of its sintering time. The microcutting wear mechanisms predominated during the grinding of the $\mathrm{Si}_{3} \mathrm{~N}_{4}$ ceramics with the $\mathrm{Al}_{2} \mathrm{O}_{3}$ abrasives. The hardness of ceramic material had a great effect on its wear resistance. The wear of ceramics at friction with $18 \mathrm{Cr}-8 \mathrm{Ni}$ type of austenitic stainless steels was several times higher compared to friction with 14Cr type of ferritic stainless steel. Under these conditions, the microcracking wear mechanisms predominated.
\end{abstract}

Keywords: silicon nitride, microstructure, mechanical properties, wear resistance

\section{INTRODUCTION}

Silicon nitride-based engineering ceramics belong to the ceramic materials with the largest spectrum of application. Excellent thermomechanical properties, in combination with low density, high hardness, good chemical stability and favourable friction properties predestine the silicon nitride $\left(\mathrm{Si}_{3} \mathrm{~N}_{4}\right)$ for utilizing in high temperature, abrasive wear, corrosive and thermal cycle environments. This ceramic material can be utilised in friction junction of combustion engines which are exposed to abrasive, adhesive, erosive or corrosive wear conditions [1-3].

Silicon nitride ceramics is mainly applied in hybrid bearings which consist of steel outer and inner races and ceramic rolling elements made of $\mathrm{Si}_{3} \mathrm{~N}_{4}$. Silicon nitride ceramics is lighter compared to steel, which is an important advantage mainly for application in aviation and space industry. Higher hardness of silicon nitride compared to steel offers its wear resistance. Higher stiffness is an important property for super precise bearings. Other properties of the $\mathrm{Si}_{3} \mathrm{~N}_{4}$ ceramics, such as good corrosion resistance, low thermal expansion and high electric resistance are important for hybrid bearing in many demanding applications [4]. The ceramic components are not sensitive to hydrogen embrittlement, but this negative effect is possible in the steel components of bearings [5]. On the basis of all these advantages, hybrid bearings possess higher power output at weak lubrication and under polluted conditions [6].

However, silicon nitride ceramics, like ceramic in general, has a low fracture toughness compared to classic bearing materials. One of the efforts in the silicon nitride research is to achieve favourable values of fracture toughness and to enhance the reliability of ceramic components made of silicon nitride.

Indentation methods have been preferentially used for evaluation of basic mechanical properties of ceramic materials such as the hardness and fracture toughness [7, 8]. A Vickers or Knoop indenter is impressed into the tested material when using these indentation methods. Both hardness and fracture toughness can be calculated from the dimensions of the created imprints and initiated cracks. The imprints can be used for initiation of the defects which simulate surface defects in the 
tribological system $[9,10]$. Several authors have modelled the initiation of defects by using either the finite element method or advanced calculation methods with the simulation of cracks propagation based on the cohesive behaviour of material [7, 8, 11-15].

Wear mechanisms are important for the evaluation of silicon nitride wear in friction couple - either ceramic-ceramic or ceramic-metal. Some theoretical models were proposed $[16,17]$ and subsequently specified and verified experimentally $[2,15,18]$. The molecular mechanics theory [17] considers the effect of macro and micro protrusions at the contact surface and mediation of interatomic forces. In ceramic materials, the surface protrusions deform elastically, and the contact pressure depends on the radius of impressed micro-protrusion. The density of micro protrusions contacts increases along with the load; hence, real surface grows. Abrasive wear is the most common wear of $\mathrm{Si}_{3} \mathrm{~N}_{4}$ based ceramic materials. Surface damage at this wear can be described be two basic mechanisms - microcutting and microcracking. The transfer from microcutting to microcracking wear mechanism can lead to a decrease of the wear resistance because of the high hardness of ceramic materials. Microcutting can be expected as dominant wear mechanisms at good fracture toughness and high hardness of worn ceramics but which is lower compared to abrasive material. The inclination to microcracking depends mainly on the fracture toughness of the worn ceramic material and load conditions. The material with low fracture toughness will be preferentially worn by microcracking. This will lead to a decrease of the wear resistance of material still at high hardness.

The $H V / K_{I C}$ parameter ratio (hardness / fracture toughness) can be used for predicting the wear of fragile materials when abrasive wear is a predominant wear mechanism [19]. At low value of this ratio, plastic microcutting mechanism predominates and the hardness of worn material has the greatest effect on wear $(W)$. The wear extent can be expressed by relation $W \sim H V^{-1}$. At high value of this ratio, the microcracking mechanism predominates and wear extent can be described by relation $W \sim H V / K_{I C}$. This subject was studied in works [20-23]. The tested material is usually loaded in condition of cyclic fatigue and under various conditions (with and without lubricant) and at various temperatures.
Both an adhesive effect and increased wear extent of the $\mathrm{Si}_{3} \mathrm{~N}_{4}$ ceramics were found at the sliding friction of ceramic-metal couple which was the consequence of the penetration of hard worn ceramic products into a softer metallic surface. Separation of several grains from ceramic bulk during the initial stage of friction, when high local stresses affect, is probably the basic reason of abrasive particles creation in the friction zone. Simultaneously, the adhesion processes occur, and these are joined with both the transfer of thin metallic layer on ceramic surface and the interaction of this layer with surface of metallic part. The authors of work [24] studied the wear of $\mathrm{Si}_{3} \mathrm{~N}_{4}$ in the contact with different materials such as $\mathrm{Al}$ alloy, $\mathrm{Cu}$ alloy and stainless steel at various sliding speeds. The highest wear of both tested materials was observed at the friction of $\mathrm{Si}_{3} \mathrm{~N}_{4}$ with stainless steel. Strong adhesion between $\mathrm{Si}_{3} \mathrm{~N}_{4}$ and stainless steel was observed. Wear increased along with the sliding speed. The effect of sliding speed in the interval from 1 to $20 \mathrm{~m} \cdot \mathrm{s}^{-1}$ on the wear of sliding couple $\mathrm{Si}_{3} \mathrm{~N}_{4}$-Inconel 718 was evaluated in the work [25]. The mechanical wear of a ceramic material was observed at low sliding speed. The values of friction coefficients were high and wear the values were relatively low. At medium values of sliding speeds, the transfer from the mechanical to tribochemical wear was observed in the ceramic material. At high values of sliding speed, the tribochemical wear was dominant, the values of friction coefficients were low and the wear values were high.

\section{EXPERIMENT}

The experimental materials were prepared by hot pressing in nitrogen atmosphere. The sintering additives $\mathrm{Y}_{2} \mathrm{O}_{3}$ and $\mathrm{Al}_{2} \mathrm{O}_{3}$ were added to initial $\mathrm{Si}_{3} \mathrm{~N}_{4}$ powder in the portion which guaranteed the creation of $5 \mathrm{wt} . \%$ of yttrium aluminium garnet $\left(\mathrm{Y}_{3} \mathrm{Al}_{5} \mathrm{O}_{12}\right.$ or $\left.\mathrm{YAG}\right)$. The YAG crystalline phase is created from sintering additives and supports sintering process. Because of low diffusion coefficient of the $\mathrm{Si}_{3} \mathrm{~N}_{4}$ ceramics, it is not possible to reach $\mathrm{Si}_{3} \mathrm{~N}_{4}$ fully dense material only by sintering in solid phase, without the sintering additives creating the liquid crystalline phase during the sintering process [26-28]. The hot pressing of the experimental materials $\mathrm{Si}_{3} \mathrm{~N}_{4}$ with 5 wt.\% YAG was performed at the temperature of $1680^{\circ} \mathrm{C}$ and pressure of $34 \mathrm{MPa}$. Two various sintering times, 
i.e. 5 and $30 \mathrm{~min}$, were applied and the effects of sintering time on the density, microstructure, hardness, fracture toughness and wear resistance were studied.

The densities of the hot pressed ceramics were measured with the Archimedes' method. The microstructures of the hot pressed ceramics were observed using a scanning electron microscope JEOL IT-300-LV. Hardness and fracture toughness were determined by means of the Vickers indentation method. The wear resistance of silicon nitride was studied both during grinding of the $\mathrm{Si}_{3} \mathrm{~N}_{4}$ ceramics with the $\mathrm{Al}_{2} \mathrm{O}_{3}$ abrasive paper and friction of two different sliding couples: the $\mathrm{Si}_{3} \mathrm{~N}_{4}$ ceramics - austenitic stainless steel $18 \mathrm{Cr}-8 \mathrm{Ni}$ type, and the $\mathrm{Si}_{3} \mathrm{~N}_{4}$ ceramic - chromium stainless steel $14 \mathrm{Cr}$ type. The abrasive wear resistance of $\mathrm{Si}_{3} \mathrm{~N}_{4}$ at grinding with the $\mathrm{Al}_{2} \mathrm{O}_{3}$ abrasive was evaluated by pin on disk method using the equipment documented in Figure 1. The cylindrical samples of $\mathrm{Si}_{3} \mathrm{~N}_{4}$ with a diameter of $8.4 \mathrm{~mm}$ and a height of $10 \mathrm{~mm}$ were placed in the contact with the $\mathrm{Al}_{2} \mathrm{O}_{3}$ grinding paper with a graininess of $120 \mu \mathrm{m}$. Archimedean spiral was used as the grinding trajectory with the total length of $125 \mathrm{~m}$. Dry friction was chosen during the pin on disk tests of $\mathrm{Si}_{3} \mathrm{~N}_{4}$ ceramic samples with radial movement of $1.5 \mathrm{~mm}$ per revolution and maximal grinding speed of $0.5 \mathrm{~m} . \mathrm{s}^{-1}$. The contact pressure was $1.5 \mathrm{MPa}$. The discs made of $18 \mathrm{Cr}-8 \mathrm{Ni}$ and $14 \mathrm{Cr}$ steels with a diameter of $50 \mathrm{~mm}$ and a thickness of $10 \mathrm{~mm}$ were counterparts in contact with the $\mathrm{Si}_{3} \mathrm{~N}_{4}$ cylindrical samples with a diameter of $8.4 \mathrm{~mm}$ and a height of $10 \mathrm{~mm}$ when studying friction of two ceramic-steel sliding couples. The circle with a diameter of $50 \mathrm{~mm}$ was used as the friction trajectory during the friction tests and it represented the sliding speed of $0.5 \mathrm{~m} . \mathrm{s}^{-1}$. Total length of sliding trajectory was $1000 \mathrm{~m}$ and the contact pressure was $10 \mathrm{MPa}$.

The wear resistance of samples was determined based on the volume loss of the samples relative to the grinding trajectory according to the equation (1):

$$
W=\frac{\Delta m}{\rho \cdot l}\left[m m^{3} \cdot m^{-1}\right]
$$

where $W$ is the volume loss of the sample, $\Delta m$ is the weight loss of the sample, $r$ is the density of the sample and $l$ is the grinding trajectory of the sample.

\section{RESULTS AND DISCUSSION}

\section{Densification and microstructure of $\mathrm{Si}_{3} \mathrm{~N}_{4}$ ceramics}

The densities of the $\mathrm{Si}_{3} \mathrm{~N}_{4}$ ceramic samples were influenced by the sintering time. They increased along with the sintering time from $3.21 \mathrm{~g} \cdot \mathrm{cm}^{-3}$ (for $5 \mathrm{~min}$ ) to $3.25 \mathrm{~g} . \mathrm{cm}^{-3}$ (for $30 \mathrm{~min}$ ). These values corresponded to the relative density from $97.23 \%$ (for $5 \mathrm{~min}$ ) to $98.51 \%$ (for $30 \mathrm{~min}$ ), which indicate good densification of these samples.

Figure 2 represents the microstructures of the $\mathrm{Si}_{3} \mathrm{~N}_{4}$ ceramics sintered for 5 and $30 \mathrm{~min}$. The microstructures of $\mathrm{Si}_{3} \mathrm{~N}_{4}$ contain equiaxed matrix of $\alpha-\mathrm{Si}_{3} \mathrm{~N}_{4}$ grains and large elongated $\beta$ $\mathrm{Si}_{3} \mathrm{~N}_{4}$ grains. Along the boundary of $\mathrm{Si}_{3} \mathrm{~N}_{4}$ phase, brittle crystalline secondary $\mathrm{Y}_{3} \mathrm{Al}_{5} \mathrm{O}_{12}$ (YAG) phase is created. The fine-grained microstructure can be seen in Fig. 2a which depicts a ceramic

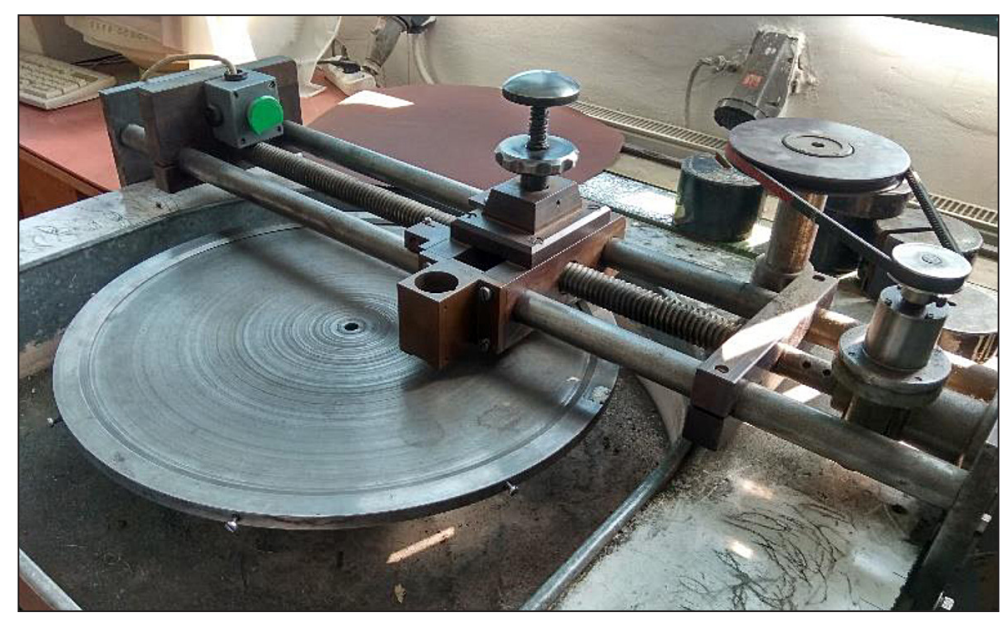

Fig. 1. Equipment used for pin on disk wear tests of $\mathrm{Si}_{3} \mathrm{~N}_{4}$ ceramics 

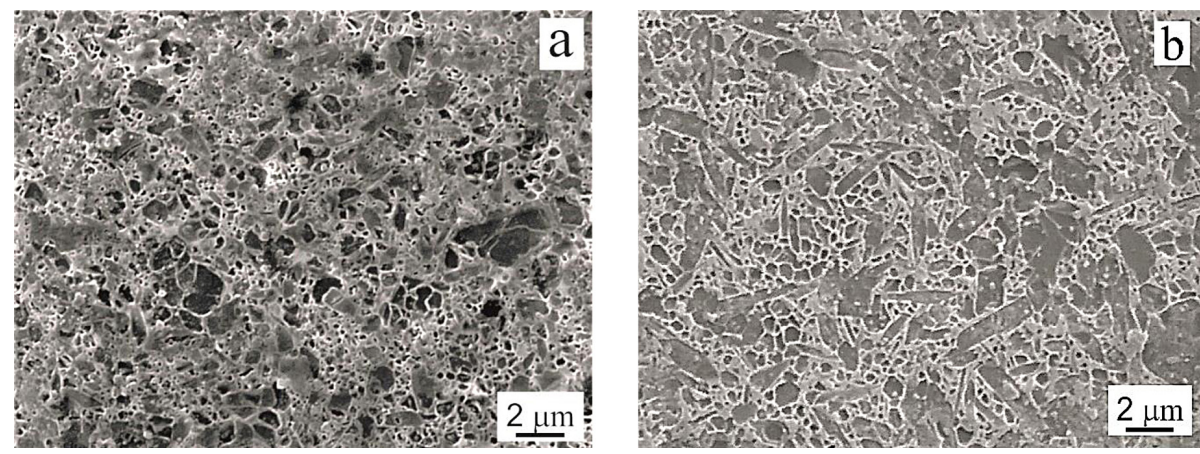

Fig. 2. Microstructure of $\mathrm{Si}_{3} \mathrm{~N}_{4}$ ceramics sintered for a) $5 \mathrm{~min}$ b) $30 \mathrm{~min}$

sample sintered for $5 \mathrm{~min}$. The microstructure contains coarse $\beta-\mathrm{Si}_{3} \mathrm{~N}_{4}$ grains after the sintering time was prolonged for $30 \mathrm{~min}$ (Fig. 2b). The growth of crystals during sintering can be seen in Figure 2, the coarse grains developed with the increased sintering time.

The phase compositions of samples sintered for different times were identified with the XRD method. Only two phases $\alpha-\mathrm{Si}_{3} \mathrm{~N}_{4}$ and $\beta-\mathrm{Si}_{3} \mathrm{~N}_{4}$ were found in both specimens. However, the phases with a concentration below 5 wt.\% could not be identified using the XRD method. The transformation stage from initial $\alpha-\mathrm{Si}_{3} \mathrm{~N}_{4}$ phase to final $\beta-\mathrm{Si}_{3} \mathrm{~N}_{4}$ phase increases with the sintering time. The portion of the $\beta-\mathrm{Si}_{3} \mathrm{~N}_{4}$ phases was $45 \mathrm{wt} . \%$ at sintering time of $5 \mathrm{~min}$, and it increased to $75 \mathrm{wt} . \%$ with the prolongation of the sintering time to $30 \mathrm{~min}$. The whole transformation of $\alpha-\mathrm{Si}_{3} \mathrm{~N}_{4}$ to $\beta-\mathrm{Si}_{3} \mathrm{~N}_{4}$ phase was not achieved under the studied sintering conditions.

\section{Mechanical properties $\mathrm{Si}_{3} \mathrm{~N}_{4}$ ceramics}

Figure 3 represents the effect of sintering time on the hardness and fracture toughness of the $\mathrm{Si}_{3} \mathrm{~N}_{4}$ ceramics. The hardness decreases with the prolongation of the sintering time. The effect of $\beta-\mathrm{Si}_{3} \mathrm{~N}_{4}$ phase portion on the hardness and fracture of $\mathrm{Si}_{3} \mathrm{~N}_{4}$ - the YAG system was investigated in the study [29]. A decrease of hardness with an increased $\beta-\mathrm{Si}_{3} \mathrm{~N}_{4}$ portion was found in this study. The transformation of $\alpha-\mathrm{Si}_{3} \mathrm{~N}_{4}$ to $\beta-\mathrm{Si}_{3} \mathrm{~N}_{4}$ phase develops during the sintering and is accompanied by the formation and growth of rodlike $\beta-\mathrm{Si}_{3} \mathrm{~N}_{4}$ grains. The $\beta-\mathrm{Si}_{3} \mathrm{~N}_{4}$ grains give the poorer values of hardness than the equiaxed $\alpha-\mathrm{Si}_{3} \mathrm{~N}_{4}$ grains [30]. This confirms the relationship between the hardness and microstructure and their progress with the prolongation of the sintering time.

The values of fracture toughness $\mathrm{K}_{\mathrm{IC}}$ in Figure 3 increase slightly with the prolongation of the sintering time (to $30 \mathrm{~min}$ ). It has been reported that the hardness of $\alpha-\mathrm{Si}_{3} \mathrm{~N}_{4}$ single crystals is higher than that of $\beta$-single crystals. The large elongated $\beta-\mathrm{Si}_{3} \mathrm{~N}_{4}$ grains with high aspect ratio deflect the propagation of cracks, thus increase the fracture toughness of ceramics. The values of fracture toughness $\mathrm{K}_{\mathrm{IC}}$ increases along with the elongated $\beta-\mathrm{Si}_{3} \mathrm{~N}_{4}$ grains portion.

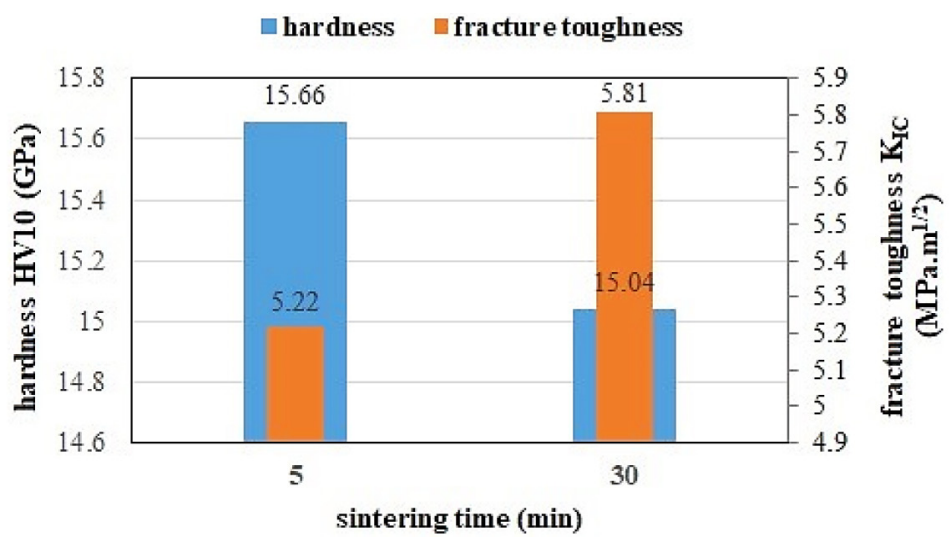

Fig. 3. Effect of sintering time on the hardness and fracture toughness of the $\mathrm{Si}_{3} \mathrm{~N}_{4}$ ceramics 


\section{Tribological properties of the $\mathrm{Si}_{3} \mathrm{~N}_{4}$ ceramics}

\section{Wear resistance of $\mathrm{Si}_{3} \mathrm{~N}_{4}$ at grinding} with $\mathrm{Al}_{2} \mathrm{O}_{3}$ abrasive

The effect of the sintering time on the wear of the ceramic samples during pin on disk tests can be seen in Figure 4. The highest wear resistance was achieved at the sample which was pressed for only $5 \mathrm{~min}$. Both the decrease of the wear resistance and the increase of the volume lost with the prolongation of the sintering time can be seen from Figure 4 . These values are significantly influenced by the grain size of ceramics which influences the hardness. The grain size increases with the prolongation of sintering time. The portion of $\beta-\mathrm{Si}_{3} \mathrm{~N}_{4}$ phase increases at the expense of the $\alpha$ $\mathrm{Si}_{3} \mathrm{~N}_{4}$ phase with the prolongation of the sintering time which causes a gradual decrease of the hardness and thus the wear resistance of $\mathrm{Si}_{3} \mathrm{~N}_{4}$ ceramics. That is the reason for the lowest measured wear resistance values of the samples sintered for the longest time of $30 \mathrm{~min}$. The dependence between the hardness and volume loss of samples in Figure 5 confirms this effect.

The effects of the measured mechanical properties of the $\mathrm{Si}_{3} \mathrm{~N}_{4}$ ceramics on their wear properties were studied in detail and are presented in Figure 5.

Hardness has a positive effect on the wear resistance of the $\mathrm{Si}_{3} \mathrm{~N}_{4}$ ceramics (Fig. 5). Higher hardness resulted in less wear. The highest hardness was measured in the ceramics pressed for $5 \mathrm{~min}$. These samples have the smallest volume losses. The highest volume losses were measured in the samples pressed for $30 \mathrm{~min}$. These samples have the smallest hardness. The results in Figure 5 correspond well with the $W \sim H V^{-1}$ model, where the volume losses during the wear tests vary inversely in proportion to the hardness $H V$ of the ceramics.

Figure 5 also represents the effect of fracture toughness on the volume loss of ceramics samples. The worn volume increases along with the fracture toughness. The results are influenced by the grain coarsening. The maximal wear value

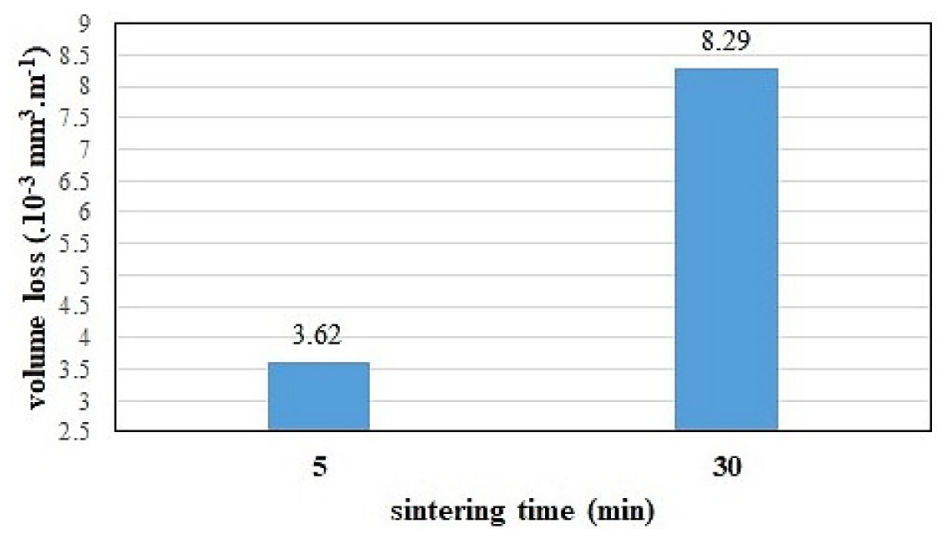

Fig. 4. Effect of sintering time on the volume loss of the $\mathrm{Si}_{3} \mathrm{~N}_{4}$ ceramics

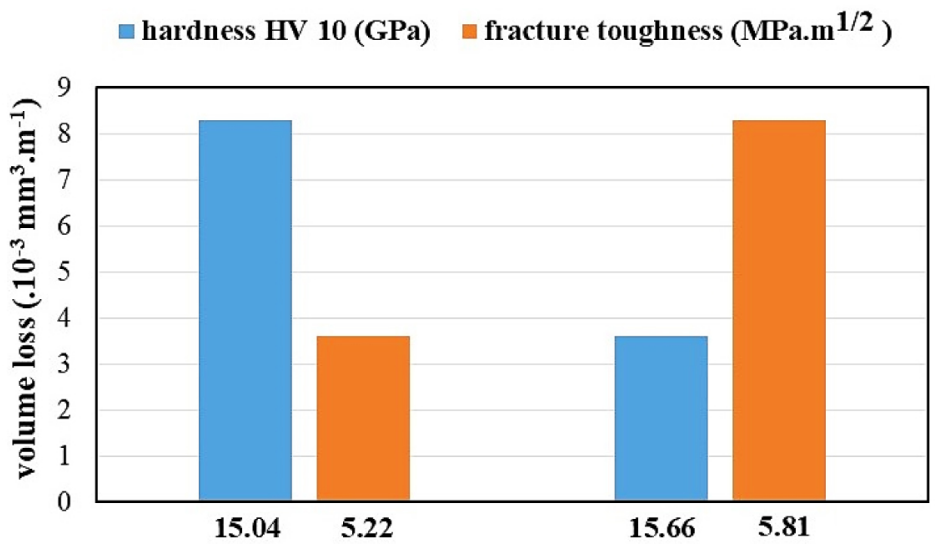

Fig. 5. Effect of hardness and fracture toughness on the volume loss of the $\mathrm{Si}_{3} \mathrm{~N}_{4}$ ceramics 
$\left(8.29 .10^{-3} \mathrm{~mm}^{3} \cdot \mathrm{m}^{-1}\right)$ was achieved at the pressing time of $30 \mathrm{~min}$, with the highest grain size values.

The sample surfaces after the grinding with $\mathrm{Al}_{2} \mathrm{O}_{3}$ abrasives are documented in Figure 6. The comparison of these sample surfaces indicates that the sample with sintering time of $30 \mathrm{~min}$ (Fig. 6b) shows a larger extent of the wear. Worn surface is formed by many pits, some cracks are visible too. On sample surface with sintering time of 5 min in Fig. 6a, fine wear of ceramic surface can be seen. Both crystalline binding phase and grain size, which is affected by the sintering time, have a significant effect on the surface damage of ceramics. It is known that the grain coarsening causes the generation of stresses in the microstructure of silicon nitride. These stresses are the consequence of different thermal expansion of the crystalline binding phase, which surrounds individual $\mathrm{Si}_{3} \mathrm{~N}_{4}$ ceramic grains. The thermal expansion coefficient of crystalline binding phase YAG $\left(\sim 7 \cdot 10^{-6}{ }^{\circ} \mathrm{C}^{-1}\right)$ is higher compared to the $\mathrm{Si}_{3} \mathrm{~N}_{4}$ ceramics $\left(\sim 2,2 \cdot 10^{-6}{ }^{\circ} \mathrm{C}^{-1}\right)$. Grain coarsening influences the distribution of the binding phase which coagulates to larges islands in the coarse-grained microstructure. These islands of crystalline binding phase present weak places in microstructure because of the stresses generated by different thermal expansion. These stresses, together with low fracture toughness values, cause an easy fall out of grain at wearing of ceramics. The coarse grains decrease the toughness which can lead to intensive microcracking. Figure $6 \mathrm{~b}$ confirms the negative effect of grain coarsening of the $\mathrm{Si}_{3} \mathrm{~N}_{4}$ microstructure on its wear resistance. The surfaces in Figure $6 \mathrm{~b}$ show a larger extent of wear with significant damage. The samples sintered for a shorter time (5 min) show a finer wear of the surface which is caused by higher hardness and finer grain compared to the samples sintered for a longer time (30 $\mathrm{min})$.

\section{Wear resistance of Si3N4 at dry friction with stainless steels}

The disc counterparts made of austenitic chromium nickel stainless steels $18 \mathrm{Cr}-8 \mathrm{Ni}$ type and ferritic chromium stainless steels $14 \mathrm{Cr}$ type were used in these tests. Stainless steel $18 \mathrm{Cr}-8 \mathrm{Ni}$ was soft annealed and had the average hardness of $191 \mathrm{HV}$. It has tendency to seize and cold weld at sliding friction without lubrication. It tends to stick to the tool surface during machining. The stainless steel $14 \mathrm{Cr}$ disc samples used for friction tests were austenitized at $980^{\circ} \mathrm{C}$ and quenched in air and subsequently tempered at $450^{\circ} \mathrm{C}$ for 2 hours and cooled in air. They had the average hardness of $516 \mathrm{HV}$. The results from the wear tests of $\mathrm{Si}_{3} \mathrm{~N}_{4}$ ceramics at the friction with both stainless steel materials are plotted in Figure 7. The wear of the $\mathrm{Si}_{3} \mathrm{~N}_{4}$ ceramics in Figure 7 at the friction with the $18 \mathrm{Cr}-8 \mathrm{Ni}$ austenitic stainless steels is several times higher compared to the wear of the $\mathrm{Si}_{3} \mathrm{~N}_{4}$ ceramics at the friction with the $14 \mathrm{Cr}$ ferritic stainless steel. The $14 \mathrm{Cr}$ ferritic stainless steel has several times higher wear resistance compared to the $18 \mathrm{Cr}-8 \mathrm{Ni}$ austenitic stainless steels. The wear extent of experimental steels was influenced by their hardness. The $14 \mathrm{Cr}$ ferritic stainless steel has almost three times higher hardness $18 \mathrm{Cr}-8 \mathrm{Ni}$ than austenitic stainless steels. The wear of experimental steels was affected by the wear mechanisms too. At reciprocal friction, the adhesion between the surfaces of $\mathrm{Si}_{3} \mathrm{~N}_{4}-14 \mathrm{Cr}$ couple was not so strong as between the surfaces of $\mathrm{Si}_{3} \mathrm{~N}_{4}-18 \mathrm{Cr}-8 \mathrm{Ni}$ couple. This fact was confirmed at the observation of worn surfaces of steel discs. More significant wear of $18 \mathrm{Cr}-8 \mathrm{Ni}$ austenitic stainless steel was noticed compared to the wear of $14 \mathrm{Cr}$ ferritic stainless steel during this observation, which is documented in Figure 8.
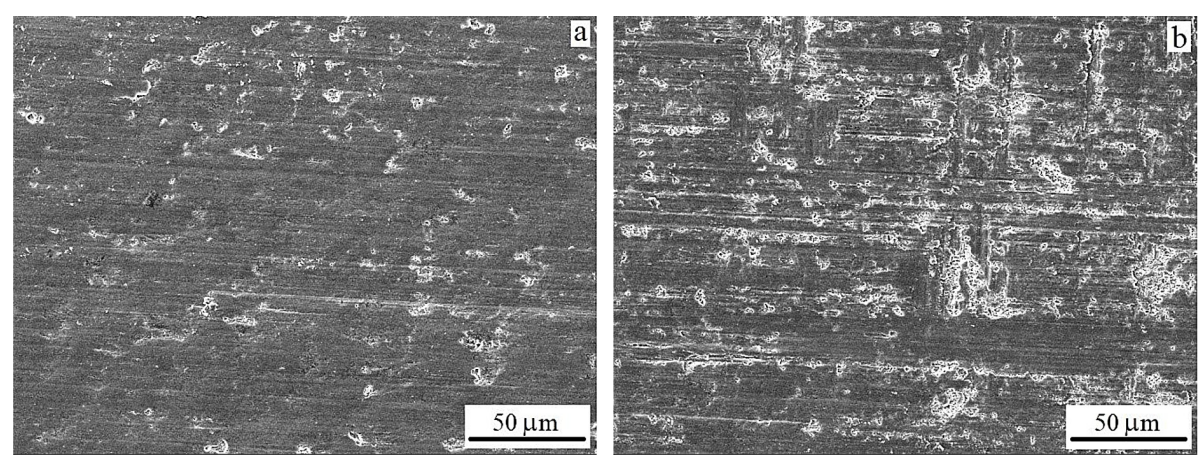

Fig. 6. Surface of $\mathrm{Si}_{3} \mathrm{~N}_{4}$ ceramics sintered for a) $5 \mathrm{~min}$ b) 30 min after grinding with $\mathrm{Al}_{2} \mathrm{O}_{3}$ abrasive 


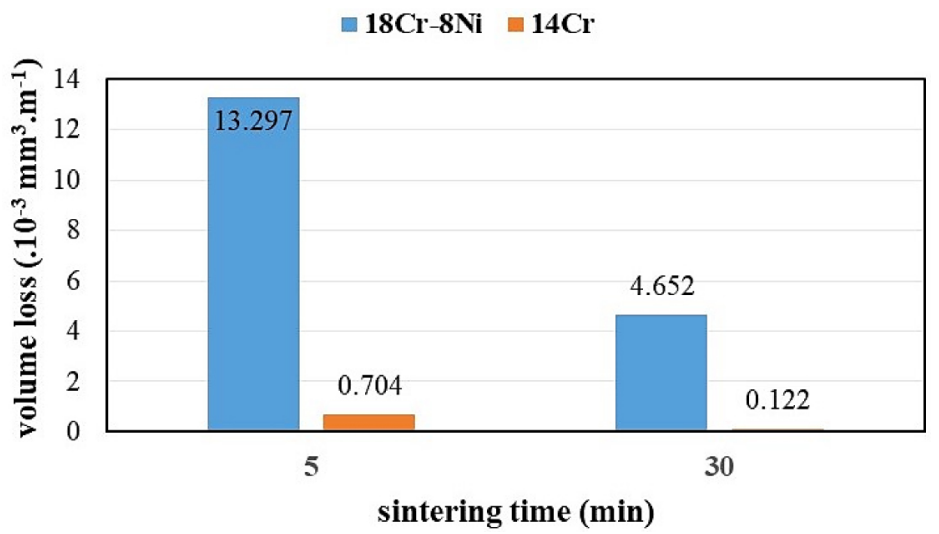

Fig. 7. Effect of the sintering time on volume loss of $\mathrm{Si}_{3} \mathrm{~N}_{4}$ during dry friction with stainless steels

The transfer of ceramic layers on the surfaces of steels and metallic layers on the surfaces of ceramics was detected in Figure 8. Dominant transfer of ceramics on the surface of steel was observed at the couple $\mathrm{Si}_{3} \mathrm{~N}_{4}-$ $18 \mathrm{Cr}-8 \mathrm{Ni}$ (Fig. 8a). This observation reveals that a strong adhesive effect stems from the friction interaction of the $\mathrm{Si}_{3} \mathrm{~N}_{4}$ ceramics with austenitic stainless steel without a lubricant. This explains the higher wear of $\mathrm{Si}_{3} \mathrm{~N}_{4}$ ceramics because of the intensive micro-crack creation on the ceramic surface and below the ceramic surface in the consequence of the larger amount of the transferred metallic layer on the ceramic surface [31]. This effect can cause the extraction of ceramic grains which leads to an increased wear of $\mathrm{Si}_{3} \mathrm{~N}_{4}$. Higher surface roughness of steel disc caused by wear of this surface could contribute to a significant damage of the ceramic surface.

The decrease of volume loss of the $\mathrm{Si}_{3} \mathrm{~N}_{4}$ ceramics with a reduction of its hardness is plotted in Figure 9. The highest wear resistance did not reach the samples with the highest hardness but the samples with the highest fracture toughness (Fig. 10).
The achieved results indicate that despite the known positive effect of the hardness of ceramic materials on their wear resistance, the fracture toughness of the $\mathrm{Si}_{3} \mathrm{~N}_{4}$ ceramics will be an important property at the dry friction contact of these ceramics with experimental stainless steels. Creation of strong adhesive joints at the friction of ceramics with $18 \mathrm{Cr}-8 \mathrm{Ni}$ austenitic stainless steel caused that the wear of ceramics in contact with weaker austenitic stainless steel was more significant compared to the wear in contact with hard ferritic stainless steel.

The presented results show that the adhesion processes take part during the dry friction between ceramics and stainless steels. A similar effect was confirmed in works $[24,32]$ when adhesion was observed at wearing of nitride ceramic with stainless steel. Breaking of the created adhesive joints caused the transport of the metallic layer on the ceramic surface during the relative moving of interactive friction surfaces. Beside this fact, the tribochemical reactions were found between the $\mathrm{SiO}_{2}$ layer, which is created on $\mathrm{Si}_{3} \mathrm{~N}_{4}$ surface by the $\mathrm{O}_{2}$ impact presented in air, and $\mathrm{FeO}$ layer created in consequence of the oxidation of steel disc $\left(\mathrm{SiO}_{2}+\mathrm{FeO} \rightarrow \mathrm{FeSiO}_{3}\right)$.
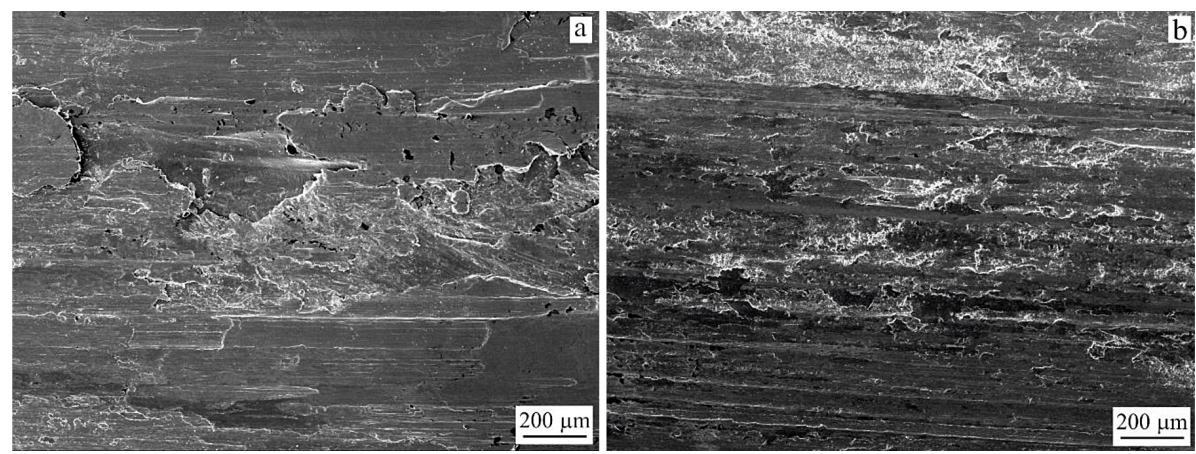

Fig. 8. The surfaces of a) $18 \mathrm{Cr}-8 \mathrm{Ni}$ b) $14 \mathrm{Cr}$ stainless steel after friction with $\mathrm{Si}_{3} \mathrm{~N}_{4}$ ceramics 


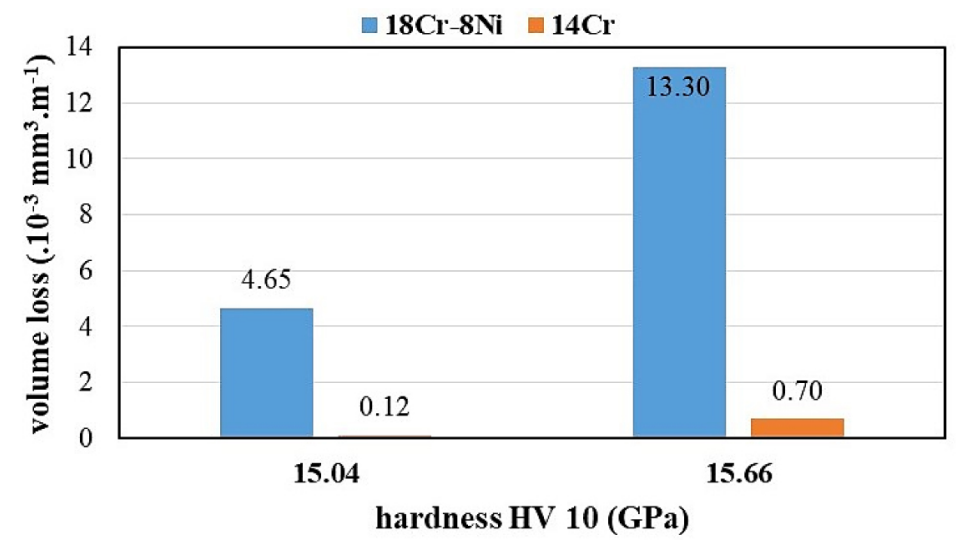

Fig. 9. Effect of hardness of $\mathrm{Si}_{3} \mathrm{~N}_{4}$ on its wear during the friction with stainless steels

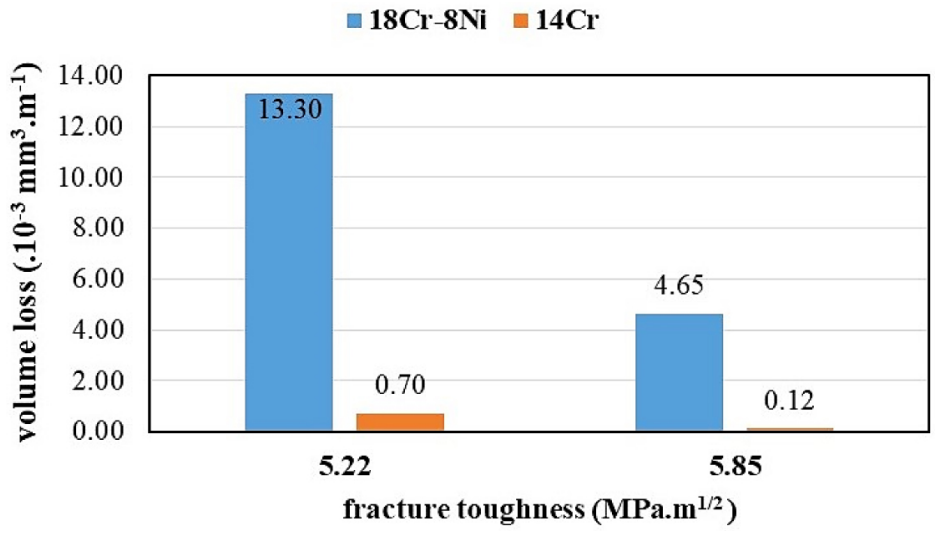

Fig. 10. Effect of fracture toughness of $\mathrm{Si}_{3} \mathrm{~N}_{4}$ its on wear during the friction with stainless steels

\section{CONCLUSIONS}

The aim of the paper was to investigate the effect of sintering time on the chosen mechanical and tribological properties of hot pressed $\mathrm{Si}_{3} \mathrm{~N}_{4}$ based ceramics. The mechanical properties of the $\mathrm{Si}_{3} \mathrm{~N}_{4}$ ceramics such as hardness and fracture toughness were evaluated. The tribological properties of the $\mathrm{Si}_{3} \mathrm{~N}_{4}$ ceramics were studied during grinding of this ceramics with the $\mathrm{Al}_{2} \mathrm{O}_{3}$ abrasives and during the friction of this ceramics with two types of stainless steels. A direct dependence of the studied properties on the ceramic microstructure was confirmed. The microstructure of the $\mathrm{Si}_{3} \mathrm{~N}_{4}$ ceramics was controlled by hot pressing parameters. On the basis of the realized measurements, the following preliminary conclusions can be drawn:

1 . Both the grain coarsening of the hot pressed $\mathrm{Si}_{3} \mathrm{~N}_{4}$ ceramics and the $\beta-\mathrm{Si}_{3} \mathrm{~N}_{4}$ phase portion increase are consequence of the prolongation of the sintering time which has a gradual effect on decrease of the hardness of $\mathrm{Si}_{3} \mathrm{~N}_{4}$ ceramics.
Shorter sintering time of $5 \mathrm{~min}$ is more favourable for the hardness of ceramics because of the positive effect of fine-grained microstructure on the hardness values. The ceramic sintered for a shorter time contains a larger portion of the untransformed $\alpha-\mathrm{Si}_{3} \mathrm{~N}_{4}$ phase, which has higher hardness compared to the tougher $\beta-\mathrm{Si}_{3} \mathrm{~N}_{4}$ phase.

2. The fracture toughness values of silicon nitride ceramics increases with the prolongation of its sintering time. The elongated grains of the $\beta-\mathrm{Si}_{3} \mathrm{~N}_{4}$ phase have a positive effect on the fracture toughness of ceramics. Increasing the stress field which is generated in vicinity of growing grains hinders the initiation or propagation of cracks.

3. The microcutting wear mechanisms predominates during the grinding of the $\mathrm{Si}_{3} \mathrm{~N}_{4}$ ceramics with the $\mathrm{Al}_{2} \mathrm{O}_{3}$ abrasives. The hardness of the ceramic material has the greatest effect on its wear resistance and can be described by the model $W \sim H V^{-1}$. 
4. Strong adhesion between the friction surfaces was observed during the wear test of the $\mathrm{Si}_{3} \mathrm{~N}_{4}$ ceramics under the conditions with dry friction mainly against $18 \mathrm{Cr}-8 \mathrm{Ni}$ stainless steel which was accompanied with strong seizing. Under these conditions, the microcracking wear mechanisms predominate. The gradual transport of the metallic layer on the surface of ceramics intensified the creation of cracks. The wear resistance of ceramics is mainly dependent on the fracture toughness of ceramics and can be described by the $W \sim H V / K_{I C}$ model.

\section{Acknowledgement}

The results given in this paper were obtained as part of VEGA 1/0298/18 research project. Support of the UVP STU Bratislava ITMS 26240220084 project is also acknowledged.

\section{REFERENCES}

1. Daubera, C., Vannucchi de Camargoa, F., Kopp Alvesa, A., Pavlovic, A., Fragassa, C., Pérez Bergmanna, C. Erosion resistance of engineering ceramics and comparative assessment through Wiederhorn and Evans equations. Wear, 432-433, 2019, 1-13.

2. Popov, V.L. Adhesive wear: Generalized Rabinowicz criteria, Facta Univ. - Ser. Mech. Eng., 6, 2018, 29-39.

3. More, S.R., Bhatt, D.V., Menghani, J.V. Recent research status on erosion wear - anoverview. Mater. Today, 4, 2017, 257-266

4. Wang, R.W. Snidle, L. Gu, Rolling contact silicon nitride bearing technology: a review of recent research. Wear, 246, 2000, 159-173.

5. Kadin, Y. Modeling of hydrogen transport in static and rolling contact. Trib. Trans., 58(2), 2015, 260-273.

6. Vieillard, C., Kadin, Y., Morales-Espejel, G.E., Gabelli, A. An experimental and theoreticalstudy of surface rolling contact fatigue damage progression in hybrid bearings with artificial dents. Wear, 364-365, 2016, 211-223.

7. Tang, Y., Yonezu, A., Ogasawara, N., Chiba, N., Chen, $\mathrm{X}$. On radial crack and halfpenny crack induced by Vickers indentation. Proc. R. Soc., A 464, 2008, 2967-2984.

8. Chen, X., Hutchinson, J.W., Evans, A.G. The mechanics of indentation induced lateral cracking. J. Am. Ceram. Soc., 88(5), 2005, 1233-1238.

9. Niihara, K., Morena, R., Hasselman, D.P.H. Evalu- ation of KIC of brittle solids by theindentation method with low crack-to-indentation ratios. J. Mater. Sci. Lett., 1(1), 1982, 13-16.

10. Kida, K., Urakami, T., Yamazaki, T., Kitamura, K. Surface crack growth of silicon nitride bearings under rolling contact fatigue. Fatigue Fract. Eng. Mater. Struct., 27, 2004, 657-668.

11. Chen, Z., Wang, X., Atkinson, A., Brandon, N. Spherical indentation of porous ceramics: cracking and toughness. J. Eur. Ceram. Soc., 36, 2016, 3473-3480.

12. Kadina, Y., Mazaheria, M., Zolotarevsky, V., Vieillarda, Ch., Hadfield, M. Finite elements based approaches for the modelling of radial crack formation upon Vickers indentation in silicon nitride ceramics. Journal of the European Ceramic Society, 39(14), 2019, 4011-4022.

13. Hyun, H.G., Rickhey, F., Lee, J.H., Hahn, J.H., Lee, H. Characteristics of indentation cracking using cohesive zone finite element techniques for pyramidal indenters. Int.J. Solids Struct., 51, 2014, 4327-4335.

14. Yonezu, A. Hara, T. Kondo, T. Hirakata, H. Minoshima, K. Evaluation of threshold stress intensity factor of hydrogen embrittlement cracking by indentation testing. Mater. Sci. Eng., A 531, 2012, 147-154.

15. Rickhey, F., Marimuthu, K.P., Lee, H. Investigation on indentation cracking-based approaches for residual stress evaluation. Materials, 10 (4), 2017 , $1-16$.

16. Rabinowicz, E. Friction and wear of materials. Second Edition, John Wiley \& Sons, 1995.

17. Kragel'skij, I.V., Dobychin, M.N., Kombalov, V.S. Friction and wear, Calculation Methods. Oxford: Pergamon Press, 1982

18. Lee, J.H., Gao, Y.F., Johanns, K.E., Pharr, G.M. Cohesive interface simulations of indentation cracking as a fracture toughness measurement method for brittle materials. Acta Mater., 60, 2012, 5448-5467.

19. Švec, P., Brusilová, A. Tribologické vlastnosti nitride kremíka. Nakladatel'stvo STU, 2011.

20. Raga, R., Khadera, I., Chlup, Z., Kailer, A. Damage progression in silicon nitride undergoing nonconforming hybrid cyclic contact. International Journal of Fatigue, 105, 2017, 97-110.

21. Brizmer, V., Gabelli, A., Vieillard, C., MoralesEspejel, G.E. An experimental and theoretical study of hybrid bearing micropitting performance under reduced lubrication. Tribol. Trans, 58, 2015, 829-835.

22. Reis, P., Davim, J.P., Xu, X., Ferreira, J.M.F. Friction and wear behaviour of betasilicon nitride-steel couples under unlubricated conditions. Mater. Sci. 
Technol., 22, 2006, 247-52.

23. Zhou, J., Wu, G. Experimental study of cyclic rolling-contact fatigue of silicon nitride balls. Tribol, Trans, 52, 2009, 663-70.

24. Akdogan, G. Stolarski, T.A. Wear in metal/silicon nitride sliding pairs. Ceramics International, 29, 2003, 435-446

25. Khadera, I., Renz, A., Kailer, A. A wear model for silicon nitride in dry sliding contact against a nickel-base alloy. Wear, 376-377(A), 352-362.

26. Yang, J. F., Ohji, T. Influence of Yttria-Alumina Content on Sintering Behavior and Microstructure of Silicon Nitride Ceramics. J. Amer. Soc., 83, 2000, 2094-2096.

27. Bellosi, A., Babini, G. N. Effects of raw powders on microstructure and properties of Si3N4-based ceramics. Key Engineer. Materials, 161-163, 1999, 203-208.

28. Zhang, Y. H., Edwards, L., Plumbridge, W.J. Crack Healing in a Silicon Nitride Ceramic. J. Amer. Ceram. Soc., 81, 1998, 1861-1868.

29. Kawaoka, H., Choa, Y. H., Niihara, K. Relationship between Microstructure and Mechanical Properties for Silicon Nitride Based Ceramics Fabriacted by PECS. Key Eng. Mater., 161-163, 1998, 225-228.

30. Nakamura, M., Hirao, K. Wear behaviour of aSi3N4 ceramics reinforced by rod-like b-Si3N4 grains. Wear, 254, 2003, 94-102.

31. Xing-Zhong Z., Jia-Jun L., Baoliang Z. Wear behaviour of Si3N4 ceramic cutting tool material against stainless steel. Ceramics Intern., 25, 1999, 309-315. 